\title{
Multi-functional perovskites - an investigation of compositional and processing influence on microstructure, dielectric and ferroelectric properties
}

\author{
Yang Bai ${ }^{1, a}$, Huaicheng Xiang ${ }^{1,2}$, Heli Jantunen ${ }^{1}$, and Jari Juuti ${ }^{1}$ \\ ${ }^{1}$ Microelectronics Research Unit, Faculty of Information Technology and Electrical \\ Engineering, University of Oulu, 90014 Oulu, Finland \\ ${ }^{2}$ Ministry-province jointly-constructed cultivation base for state key laboratory of \\ processing for non-ferrous metal and featured materials, Key laboratory of new \\ processing technology for non-ferrous metal and materials ministry of education, \\ College of Materials Science and Engineering, Guilin University of Technology, \\ 541004 Guilin, P.R. China
}

Received 22 August 2018 / Received in final form 12 October 2018 Published online 23 August 2019

\begin{abstract}
Ba}\left(\mathrm{Ni}_{0.5} \mathrm{Nb}_{0.5}\right) \mathrm{O}_{2.75}$ (BNNO) doped $\mathrm{KNbO}_{3}(\mathrm{KN})$ and $\left(\mathrm{K}_{0.5} \mathrm{Na}_{0.5}\right) \mathrm{NbO}_{3}(\mathrm{KNN})$, abbreviated as $\mathrm{KBNNO}$ and KNBNNO, respectively, have been recently reported to co-exhibit narrow band gaps (visible range) and strong piezoelectric/pyroelectric effects simultaneously within the same material. This had never been achieved in a single ceramic material. Such a breakthrough may allure the development of fundamentally novel multi-source energy harvesters based on only one piece of material as well as advanced optoelectronic devices with multiple functions. It has been found that the window of getting the unique combination of these properties is very narrow. Even a slight shifting away from the stoichiometry of the compositions may induce a significant loss of the properties. The reasons are expected to be in the compositions and microstructure of these materials. However, detailed information - e.g. the correlation of the compositions, processing conditions, microstructure and properties - remains to be investigated for such novel materials. In this paper, the inter-influence of different doping amounts of BNNO, calcination and sintering temperatures, phase structures and defects (potassium loss and oxygen vacancy) on the dielectric and ferroelectric properties are studied. The paper reveals the principles and provides guidance to achieving good ferroelectric properties in these emerging perovskite structured materials.
\end{abstract}

\section{Introduction}

Photo-ferroelectric materials have been under investigation since the 1970s, and are experiencing extensive research recently [1-6]. In principle, photo-ferroelectrics can

a e-mail: yang.bai@oulu.fi 
provide a unique combination of semiconducting and ferroelectric properties. It is well known that semiconductors absorbing visible and ultraviolet light $(<700 \mathrm{~nm}$ wavelength, or $>1.77 \mathrm{eV}$ photon energy) are widely used as solar cells $[7,8]$. Ferroelectric materials with large polarization have the potential to exhibit strong piezoelectric and pyroelectric effects, which are extensively utilized in mechanical and thermal sensors, actuators, transducers and energy harvesters [9-12]. Therefore, the combination of these two properties will create new multi-functional materials and thus alluring the development of novel multi-functional devices such as multi-source energy harvesters and optoelectronic devices with additional functions [13-15].

Initially, photo-ferroelectrics have been intended to be used as photovoltaic materials in solar cells [4,16-22], photodiodes [23] and optical readers of ferroelectric random-access memories $[24,25]$. In terms of the photovoltaic application, photoferroelectrics can exhibit bulk photovoltaic effect which allows an open-circuit voltage higher than the band gap thanks to their non-centrosymmetric microstructure that promotes the desired photo-excited carrier separation [4]. This provides the possibility of exceeding the physical limit (Shockley-Queisser (S-Q) limit) in conventional semiconductor based solar cells [4].

However, for a long time the band gaps of photo-ferroelectric single crystals or polycrystalline ceramics such as $\mathrm{BaTiO}_{3}$ and $\mathrm{BiFeO}_{3}$ are wider than $2.7 \mathrm{eV}$, far from the ideal value of $1.34 \mathrm{eV}$ for the optimum S-Q limit $[4,6]$. This makes them less likely to effectively absorb the whole visible-range of light in the solar spectrum, thus unlikely to be widely used as photovoltaic materials in practice $[6,7,13]$. A breakthrough has then been made by Grinberg et al. with the composition of $\mathrm{Ba}\left(\mathrm{Ni}_{0.5} \mathrm{Nb}_{0.5}\right) \mathrm{O}_{2.75}(\mathrm{BNNO})$ doped $\mathrm{KNbO}_{3}(\mathrm{KN})$ - KBNNO, which exhibits a band gap of as narrow as $1.1 \mathrm{eV}$ (similar to $\mathrm{Si}$, the most commonly used photovoltaic material) [6]. Nevertheless, the reduction of band gap came with a dramatic compromise of ferroelectricity where negligible remanent polarization was observed in the KBNNO $[6,26]$.

The following breakthroughs have been made recently by Bai et al. [26,27]. The ferroelectricity of KBNNO has been greatly improved whilst a narrow band gap $(1.48 \mathrm{eV}$ direct) has been maintained. Because of the increased remanent polarization $\left(3.4 \mu \mathrm{C} / \mathrm{cm}^{2}\right)$, recognisable piezoelectric $\left(d_{33}\right)$ and pyroelectric $(\gamma)$ coefficients of $23 \mathrm{pm} / \mathrm{V}$ and $26 \mu \mathrm{C} / \mathrm{m}^{2} \mathrm{~K}$, respectively, have been obtained [26]. More importantly, A BNNO doped $\left(\mathrm{K}_{0.5} \mathrm{Na}_{0.5}\right) \mathrm{NbO}_{3}(\mathrm{KNN})-\mathrm{KNBNNO}$, has been found to co-exhibit an even larger remanent polarization $\left(11.3 \mu \mathrm{C} / \mathrm{cm}^{2}\right)$ and a band gap of $1.6 \mathrm{eV}$ (still within the visible range) [27]. Such a significant improvement has given the KNBNNO the $d_{33}$ of $100 \mathrm{pm} / \mathrm{V}$ and $\gamma$ of $128 \mu \mathrm{C} / \mathrm{m}^{2} \mathrm{~K}$ which are nearly the same with those of the parental KNN - a widely used lead-free piezoelectric material [27]. This opens the door of development of a fundamentally novel multi-source energy harvester which is able to convert solar (narrow band gap photovoltaic), thermal (pyroelectric) and kinetic (piezoelectric) energy into electricity simultaneously on only a single piece of material [27]. As shown in the previous work [27], a device made from KNBNNO has achieved the multi-function of simultaneously harvesting light, temperature fluctuation and kinetic energy, where the benefit of increased output level due to introduction of additional energy sources compared to that of conventional single source can be clearly seen. A cantilever structured multi-source energy harvester using the same principle is under patent application [28]. Figure 1 briefly summarises the previous works carried out with KBNNO and KNBNNO [26,27].

It has been found that defect dipoles, i.e. $\mathrm{Ni}^{2+}$-oxygen vacancy combinations introduced with the dopant BNNO, act as the crucial role of easing the charge transfer from the oxygen $2 p$ states at the maximum level of the valence band to the transitionmetal $(\mathrm{Nb}) d$ states at the minimum level of the conduction band in the parental compositions $\mathrm{KN}$ or KNN [6,26,27]. However, it is also widely known that due to the introduction of oxygen vacancies (referred to as 'hard' doping or acceptor doping in 


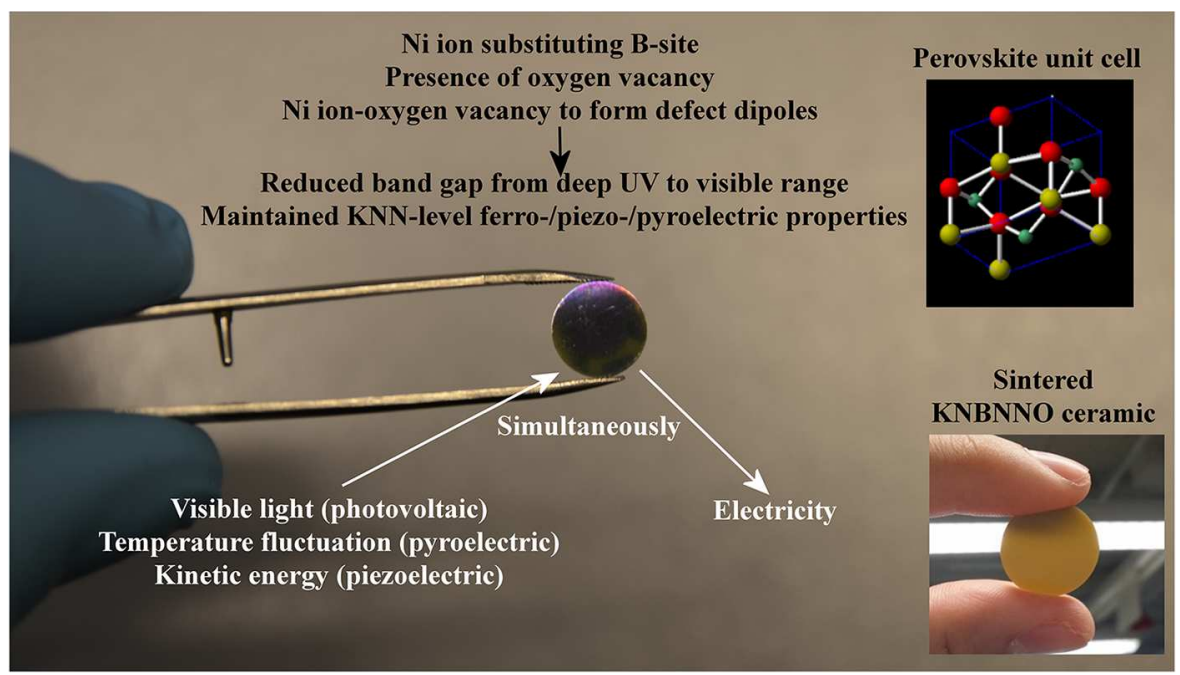

Fig. 1. Schematic summary of previous works carried out with KBNNO and KNBNNO.

piezoelectrics), the domain wall mobility is usually restricted. This is known as the domain wall pinning effect. Increased concentrations of oxygen vacancies will, in most cases, lead to even more restricted domain wall mobility and a suppressed piezoelectric and pyroelectric response. Fortunately, it has been found that for the BNNO doped KN (KBNNO), the change in the bandgap value is in a non-monotonic relationship with the BNNO fraction [6]. That is to say, with 10-40 mol.\% of dopant, the bandgaps of the KBNNO ceramics, ranging from $1.1 \mathrm{eV}$ to $1.4 \mathrm{eV}$, are not increased or decreased with the amount of the dopant (i.e. the concentration of oxygen vacancies). Meanwhile, all the above mentioned bandgaps are at the same level (smaller than $1.65 \mathrm{eV}$, the lowest photon energy of the visible light spectrum) which is preferred in the application of solar/visible light absorption and harvesting. A similar trend is also found in the BNNO doped KNN (KNBNNO) [27]. Such a phenomenon provides an opportunity to minimize the concentration of introduced oxygen vacancies, thus maximising the piezoelectric and pyroelectric properties while maintaining a narrow bandgap.

Nevertheless, the number of oxygen vacancies, i.e. different concentrations of the BNNO dopants, tend to have a more sensitive effect on the ferroelectricity compared to the concentration of $\mathrm{Ni}^{2+}$-oxygen vacancies on band gap [27]. Therefore, different compositions and fabrication processes of the KBNNO and KNBNNO need to be further studied in order to understand the correlation between their microstructure and properties. In this paper, such a detailed investigation is carried out. Compositions of $10 \mathrm{~mol} . \%$ of BNNO doped KN (with and without potassium deficit) and 2-10 mol.\% of BNNO doped KNN are studied. Together with references [26,27], this paper serves as a comprehensive and detailed report of the KBNNO and KNBNNO multi-source energy harvesting/sensing materials, providing guidance for the working principles, fabrication, optimisation and characterisation of these materials.

\section{Experimental}

\subsection{Ceramic sample fabrication}

Powders with compositions of $\left(\mathrm{K}_{1-x} \mathrm{Ba}_{0.1}\right)\left(\mathrm{Nb}_{0.95} \mathrm{Ni}_{0.05}\right) \mathrm{O}_{3-\delta} \quad(\mathrm{KBNNO}, x=0.1$ and 0.2$)$ and $(1-y)\left(\mathrm{K}_{0.5} \mathrm{Na}_{0.5}\right) \mathrm{NbO}_{3}-y \mathrm{Ba}\left(\mathrm{Ni}_{0.5} \mathrm{Nb}_{0.5}\right) \mathrm{O}_{3-\delta}$ (KNBNNO, $y=0.02$, 
$0.04,0.06,0.08$ and 0.1$)$ were prepared by solid state reaction. The two KBNNO compositions are here abbreviated to $0.1 \mathrm{KBNNO}$ and $0.2 \mathrm{KBNNO}$, respectively, according to the $x$ values. The $0.2 \mathrm{KBNNO}$ was designed to have a potassium deficit. Its comparison to the $0.1 \mathrm{KBNNO}$ has been discussed in [26]. In the same way, the five KNBNNO compositions are referred as $0.02 \mathrm{KNBNNO}, 0.04 \mathrm{KNBNNO}$, $0.06 \mathrm{KNBNNO}, 0.08 \mathrm{KNBNNO}$ and $0.1 \mathrm{KNBNNO}$ hereinafter, respectively, according to the different $y$ values. The starting reactants of $\mathrm{K}_{2} \mathrm{CO}_{3}(\geq 99 \%$, J.T. Baker, USA), $\mathrm{Na}_{2} \mathrm{CO}_{3}$ ( $\geq 99 \%$, Sigma-Aldrich, USA), $\mathrm{BaCO}_{3}$ (99.98\%, Aldrich Chemistry, USA), $\mathrm{NiO}$ (99.999\%, Aldrich Chemistry, USA) and $\mathrm{Nb}_{2} \mathrm{O}_{5}$ (99.9\%, Aldrich Chemistry, USA) were weighed according to the stoichiometry of each composition. All of the reactants were dried at $220{ }^{\circ} \mathrm{C}$ for over $4 \mathrm{~h}$ before weighing, in order to remove the potentially adsorbed water and to give precise weights with $0.01 \mathrm{mg}$ readability and $1 \mathrm{mg}$ accuracy (ES 225SM-DR, Precisa, Switzerland) [29,30]. All of the weighed reactants for each composition were loaded together into a $\mathrm{ZrO}_{2}$ jar before mixing. The mixing was carried out in the jar with ethanol using a planetary ball mill (Pulverisette 6 , Fritsch, Germany) with $\mathrm{ZrO}_{2}$ balls (3 mm diameter) for $9 \mathrm{~h}$, followed by drying at $80^{\circ} \mathrm{C}$.

The mixed powders were subjected to a one-step calcination at $800-900{ }^{\circ} \mathrm{C}$ for $4 \mathrm{~h}$ in air prior to further planetary ball milling for $12 \mathrm{~h}$ with $\mathrm{ZrO}_{2}$ balls and ethanol. No additional crushing step was applied between the calcination and the milling. The milled and dried (at $80^{\circ} \mathrm{C}$ ) powders were then mixed with $8.8 \mathrm{wt} . \%$ of binder (3.3 wt.\% polyvinyl alcohol dissolved in deionized water), and uniaxially pressed at $62 \mathrm{MPa}$ into disc-shaped green bodies with a diameter of $10 \mathrm{~mm}$. The binders in the green bodies were burnt off at $500^{\circ} \mathrm{C}$ for $10 \mathrm{~h}$ with a slow ramping rate of $1^{\circ} \mathrm{C} / \mathrm{min}$.

The subsequent sintering was carried out for $2 \mathrm{~h}$ on $\mathrm{Pt}$ foil at temperatures between $1075-1195^{\circ} \mathrm{C}$ depending on the composition. The samples were buried by sacrificial powders of the same composition in a covered alumina crucible in order to inhibit the volatilization of potassium. The sintered samples were polished with a P1200 silicon carbide abrasive paper (Eco-Wet, KWH Mirka Ltd., Finland) using ethanol as the coolant. These samples were used for XRD (X-ray diffraction).

The samples were then further finely polished to a surface roughness of 50-60 nm. The fine polishing was completed on a polisher (TegraPol-25, Struers, Cleveland, USA) with firstly a $3 \mu \mathrm{m}$ grain-sized plate (MD Dur, Struers) and diamond suspension (DiaPro Mol B3, Struers) and then with a $1 \mu \mathrm{m}$ grain-sized plate (MD Nap, Struers) and diamond suspension (DiaPro Nap B1, Struers). These samples were used for EPMA (Electron probe micro-analysis). Ag electrodes (Ag paste, DT 1402, Heraeus, Germany) were finally screen printed on both sides of the sintered and polished discs and then fired at $600{ }^{\circ} \mathrm{C}$ for $20 \mathrm{~min}$. The samples with electrodes were used in dielectric and ferroelectric characterisations.

\subsection{Characterisation}

The particle sizes of the calcined and milled ceramic powders were measured using a particle size analyser (LS 13320, Beckman Coulter, USA). The powders were also subjected to differential scanning calorimetry (DSC) and thermogravimetric analysis (TGA) (STA449, NETZSCH, Germany). The densities of all the sintered ceramic samples were measured by both the Archimedes and weight/volume methods. XRD (D8 Discover, Bruker, USA) was used to identify the phases of the calcined powders and sintered ceramics without electrodes (step size: $0.005^{\circ}$, scan speed: 1 second/step). The phase matching and determination, as well as Rietveld refinement, were carried out with the help of the 2018-version ICCD (International Centre for Diffraction Data) PDF database and software PDXL2 (Rikagu, Japan). X-ray fluorescence (XRF, AXS S4 Pioneer, Bruker, USA) was carried out in order 
to identify the compositions (e.g. potassium loss, oxygen vacancy) of the calcined powders.

The dielectric properties at room temperature were measured with an LCR meter (4284A, Hewlett Packard, USA). The ferroelectric hysteresis loops (P-E loops) were measured with a ferroelectric test system (Precision LCII, Radiant Technologies, Inc., USA). The electrical resistivity was also measured together with the P-E loop measurements using the same equipment.

\section{Results and discussions}

\subsection{Correlations of compositions, calcination/sintering temperatures and microstructures}

Calcination and sintering of both pure KN and KNN ceramics through a conventional solid-state route are more difficult to implement properly than in the case of leadbased perovskite structured ceramics such as $\mathrm{Pb}(\mathrm{Zr}, \mathrm{Ti}) \mathrm{O}_{3}$ (PZT) $[10,29,30]$. This is mainly due to the volatilization of potassium (in the form of $\mathrm{K}_{2} \mathrm{O}$ ) above $800{ }^{\circ} \mathrm{C}$ and the relatively low melting temperatures (slightly above $1000^{\circ} \mathrm{C}$ for $\mathrm{KN}$ and lower than $1200^{\circ} \mathrm{C}$ for $\left.\mathrm{KNN}\right)[10,29,30]$. As the conventional solid-state method usually prefers relatively high temperatures for more complete chemical reactions during calcination and better densification during sintering, pure KN and KNN ceramics are always sintered at well above the potassium volatilizing temperature and very close to their melting temperatures, making the process less controllable than that for PZT. However, because the conventional solid-state reaction is the most efficient and cost-effective method for the mass production of ceramics, it is still widely used to fabricate KN and KNN based ceramics [6,10,29-35]. By adding excess potassium to the starting reactants and by introducing sacrificial powder of the same compositions, the potassium loss can be minimized [10]. By careful selection of the calcination and sintering temperatures, the best possible level of densification can be achieved $[29,30]$. Similar to their pure KN and KNN counterparts, the KBNNO and KNBNNO ceramics also require a careful determination of calcination and sintering temperatures, as well as the suppression of the volatilization of potassium.

Figure 2 shows the DSC and TGA results for the mixtures of the reactants of $0.1 \mathrm{KBNNO}, 0.2 \mathrm{KBNNO}$ and $0.02 \mathrm{KNBNNO}$. The first derivatives of the DSC and TG curves are also shown for each composition. The reaction start point, reaction peak and reaction finish point are marked in the figure for each composition. At relatively low temperatures $\left(<200^{\circ} \mathrm{C}\right)$ the weight loss of water adsorbed by the hygroscopic reactants was observed as expected. At the reaction start points the decomposition of the carbonates in the reactants was initiated, accompanied by the expected massive weight loss. The reaction peaks on the DSC curves represent the highest reaction rates in the exothermic processes in the formation of the KBNNO or KNBNNO perovskite phases. The reaction finish points were determined after the peaks of the DSC curves and when no significant weight losses could be seen on the TG curve, marking the completion of the perovskite phase formation. However, for the $0.1 \mathrm{KBNNO}$ and $0.2 \mathrm{KBNNO}$ some further slight weight losses was observed even after the reaction finish points (see Figs. $2 \mathrm{a}$ and $2 \mathrm{~b}$ ). Although the same situation could hardly be seen for the $0.02 \mathrm{KNBNNO}$ (Fig. 2c) on its TG curve, according to the first derivative of the DSC curve some reactive activity was still going on at high temperatures. These weight losses were estimated as potassium loss (K loss) at above $800^{\circ} \mathrm{C}$. The $0.02 \mathrm{KNBNNO}$ suffered much less $\mathrm{K}$ loss (not recognisable on the TG curve) than the $0.1 \mathrm{KBNNO}$ and $0.2 \mathrm{KBNNO}$ (recognisable on the TG curves). A potential reason for this is that the $0.02 \mathrm{KNBNNO}$ composition finished its major 

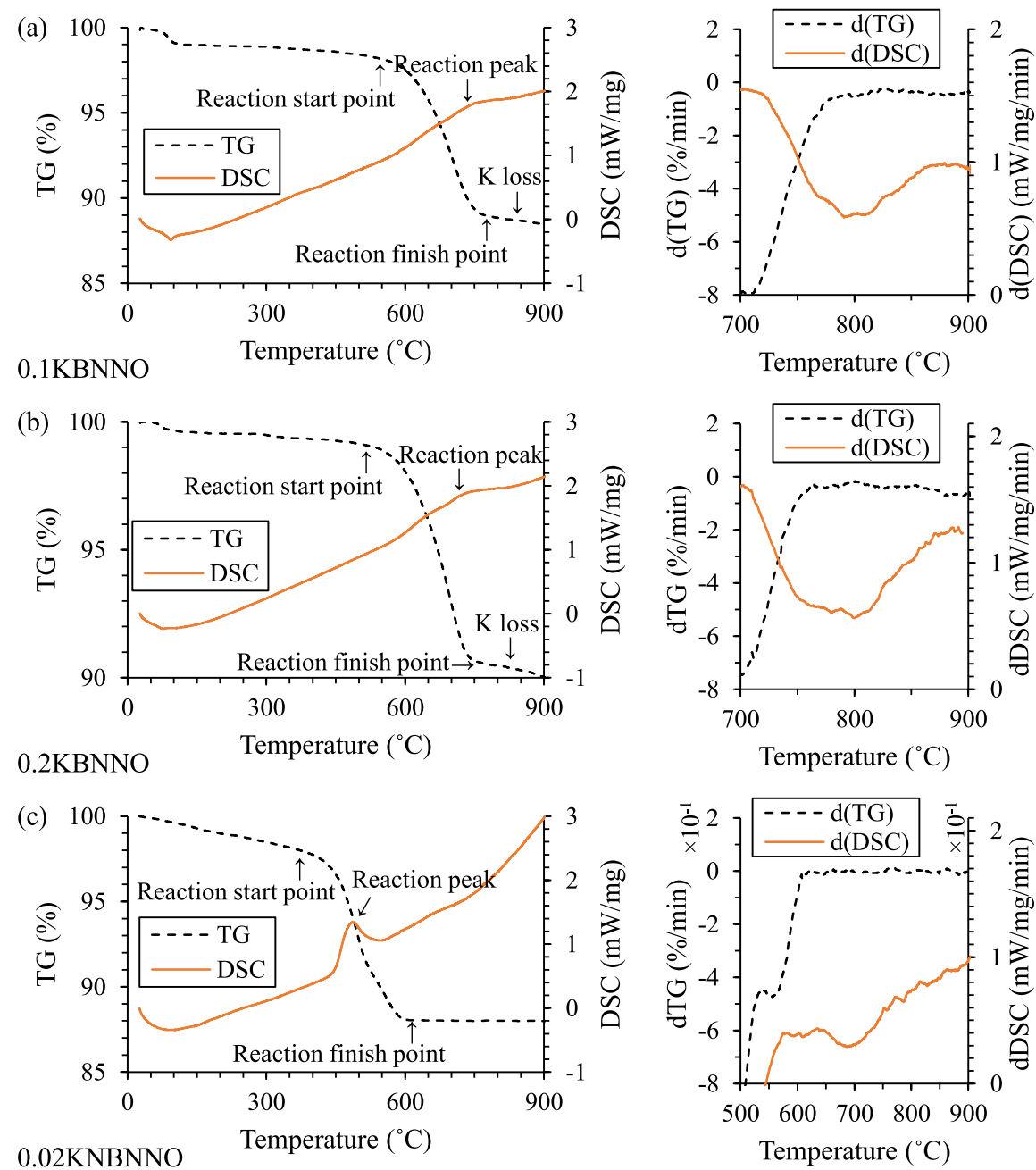

Fig. 2. DSC and TG and their first derivative data as a function of temperature for the mixtures of reactants of (a) $0.1 \mathrm{KBNNO}$, (b) $0.2 \mathrm{KBNNO}$ and (c) $0.02 \mathrm{KNBNNO}$.

reaction at a lower temperature compared to the $0.1 \mathrm{KBNNO}$ and $0.2 \mathrm{KBNNO}$ and thus had a more complete phase formation at above $800^{\circ} \mathrm{C}$. In such a case, there was a smaller chance for the $0.02 \mathrm{KNBNNO}$ to have residual/standalone, easy to volatilize K-based oxides or hydroxide. By contrast, the reaction finish points of the $0.1 \mathrm{KBNNO}$ and $0.2 \mathrm{KBNNO}$ were very close to the volatilization temperatures of the K-based compositions. Potential incomplete phase formation may allow a certain amount of standalone K-based compositions to volatilize. Meanwhile, it can be realised that the total weight loss of the $0.2 \mathrm{KBNNO}$ at $900^{\circ} \mathrm{C}$ was about $1 \%$ less than that of the $0.1 \mathrm{KBNNO}$, reflecting the difference in the theoretical total weight loss of the reactants due to the carbonates' decomposition into $\mathrm{CO}_{2}$ (11.42\% for $0.1 \mathrm{KBNNO}$ and $10.73 \%$ for $0.2 \mathrm{KBNNO}$ ). The tiny error might be caused by the potentially different ranges of the $\mathrm{K}$ loss between the two compositions. The $\mathrm{K}$ loss will be discussed in detail in the following sections. The results of the DSC and TGA for the 0.04-0.1 KNBNNO revealed similar information to that of the 0.02 KNBNNO. They are shown in Figure A1 in the appendix. 
Table 1. Summary of the reaction start point, peak, finish point and particle size for the mixtures of reactants of different KBNNO and KNBNNO compositions.

\begin{tabular}{lllll}
\hline Composition & $\begin{array}{l}\text { Reaction start } \\
\text { point }\left({ }^{\circ} \mathrm{C}\right)\end{array}$ & $\begin{array}{l}\text { Reaction } \\
\text { peak }\left({ }^{\circ} \mathrm{C}\right)\end{array}$ & $\begin{array}{l}\text { Reaction finish } \\
\text { point }\left({ }^{\circ} \mathrm{C}\right)\end{array}$ & $D_{50}(\mu \mathrm{m})$ \\
\hline $0.1 \mathrm{KBNNO}$ & 536 & 754 & 770 & 3.0 \\
$0.2 \mathrm{KBNNO}$ & 530 & 743 & 756 & 2.8 \\
$0.02 \mathrm{KNBNNO}$ & 449 & 488 & 610 & 0.20 \\
$0.04 \mathrm{KNBNNO}$ & 450 & 489 & 620 & 0.61 \\
$0.06 \mathrm{KNBNNO}$ & 451 & 491 & 620 & 0.57 \\
$0.08 \mathrm{KNBNNO}$ & 452 & 496 & 650 & 0.28 \\
$0.1 \mathrm{KNBNNO}$ & 457 & 558 & 620 & 0.42 \\
\hline
\end{tabular}
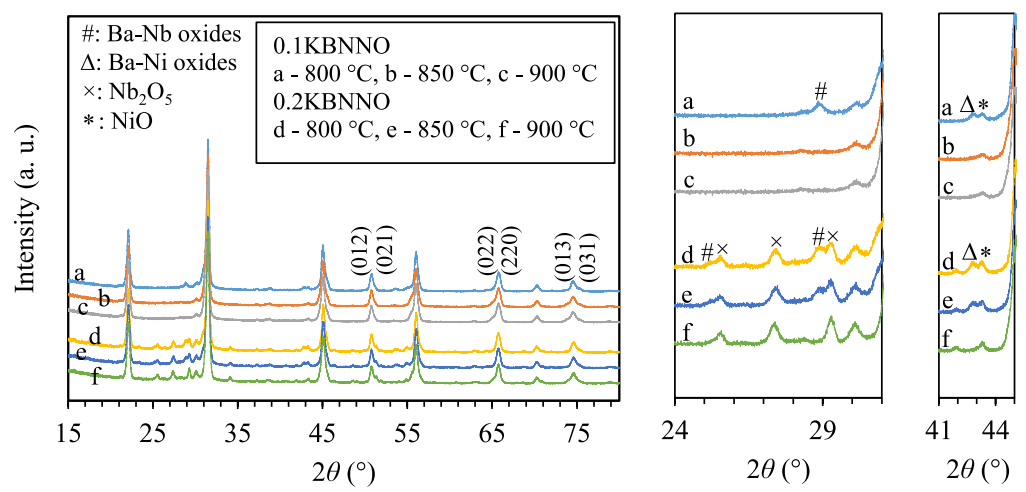

Fig. 3. XRD patterns of the $0.1 \mathrm{KBNNO}$ and $0.2 \mathrm{KBNNO}$ powders calcined at different temperatures.

Table 1 summarizes the reaction start points, peaks and finish points of all the KBNNO and KNBNNO compositions obtained from the DSC/TGA measurements. The particle sizes $\left(D_{50}\right)$ of the corresponding powders are also given in order to reveal/eliminate any significant error caused by the variation of particle size. The reaction temperatures of the five KNBNNO compositions were generally lower than those of the two KBNNO compositions. This may be because, according to the phase diagrams of the $\mathrm{Na}_{2} \mathrm{O}-\mathrm{Nb}_{2} \mathrm{O}_{5}$ and $\mathrm{K}_{2} \mathrm{O}-\mathrm{Nb}_{2} \mathrm{O}_{5}$ systems [36], for the $\mathrm{NaNbO}_{3}$ composition $\left(50\right.$ mol. $\% \mathrm{Na}_{2} \mathrm{O}+50 \mathrm{~mol} . \% \mathrm{Nb}_{2} \mathrm{O}_{5}$ ) several new solid phases of $\mathrm{Na}-\mathrm{Nb}$ oxides tend to appear (between $80-640{ }^{\circ} \mathrm{C}$ ) while for the $\mathrm{KNbO}_{3}$ composition (50 mol.\% $\mathrm{K}_{2} \mathrm{O}+50$ mol. $\% \mathrm{Nb}_{2} \mathrm{O}_{5}$ ) only one solid phase tends to appear at about $780{ }^{\circ} \mathrm{C}$. Those intermediate phases of the $\mathrm{Na}-\mathrm{Nb}$ oxides may trigger the early reaction of the reactants of the KNBNNO samples. This may also explain the phenomenon that in Figure $2 \mathrm{c}$ a consecutive weight loss at low temperatures (before the reaction started) was observed (implying continuous $\mathrm{Na}_{2} \mathrm{CO}_{3}$ decomposition and reaction with $\mathrm{Nb}_{2} \mathrm{O}_{5}$ ) while in Figures 2a and 2b little corresponding weight loss was recognised (meaning no carbonates decomposition) apart from the volatilization of the adsorbed water. Despite this, the differences of temperature within the KBNNO and KNBNNO compositions, respectively, are very small. Taking into account the possible errors caused by equipment, experiment operation and particle size, the change of dopant concentration or alkaline element concentration was considered to have a negligible effect on the reaction temperatures.

Figure 3 shows the XRD patterns of the KBNNO powders calcined at different temperatures. Weak tetragonal perovskite phases can be identified as the dominant phase in each pattern $[6,26]$. As a result of the potassium deficit, the $0.2 \mathrm{KBNNO}$ 
Table 2. Further $\mathrm{K}$ loss of the $0.1 \mathrm{KBNNO}$ and $0.2 \mathrm{KBNNO}$ calcined at $850{ }^{\circ} \mathrm{C}$ and $900{ }^{\circ} \mathrm{C}$ compared to their counterparts calcined at $800^{\circ} \mathrm{C}$.

\begin{tabular}{llll}
\hline & \multicolumn{3}{c}{ Further $\mathrm{K}$ loss compared to that of calcined at $800^{\circ} \mathrm{C}$} \\
\cline { 2 - 4 } & Calcined at $800^{\circ} \mathrm{C}$ & Calcined at $850{ }^{\circ} \mathrm{C}$ & Calcined at $900^{\circ} \mathrm{C}$ \\
\hline $0.1 \mathrm{KBNNO}$ & 0 & $-2.0 \%$ & $-2.5 \%$ \\
$0.2 \mathrm{KBNNO}$ & 0 & $-1.8 \%$ & $-2.8 \%$ \\
\hline
\end{tabular}

calcined powders always had excessive $\mathrm{Nb}_{2} \mathrm{O}_{5}$, as marked in the figure. This has been discussed in detail [2]. Meanwhile, at relatively low calcination temperatures $\left(800^{\circ} \mathrm{C}\right.$ for $0.1 \mathrm{KBNNO}, 800-850^{\circ} \mathrm{C}$ for $0.2 \mathrm{KBNNO}$ ), both compositions tended to contain a tiny amount of some Ba-Nb oxides $\left(\mathrm{Ba}_{\chi} \mathrm{Nb}_{\psi} \mathrm{Oz}\right)$ and $\mathrm{Ba}-\mathrm{Ni}$ oxides $\left(\mathrm{Ba}_{\alpha} \mathrm{Ni}_{\beta} \mathrm{O}_{\gamma}\right)$. Their corresponding peaks are marked in the figure. Although it was difficult to identify their exact compositions, both of the above mentioned oxides disappeared with a higher calcination temperature, as can be seen in the two magnified insets of Figure 3. This also well reflects the derivatives of the DSC curves shown in Figures 2a and $2 \mathrm{~b}$. At $800-850^{\circ} \mathrm{C}$, the reactions in both the $0.1 \mathrm{KBNNO}$ and $0.2 \mathrm{KBNNO}$ were accelerating, matching the diffusion of the $\mathrm{Ba}-\mathrm{Nb}$ and $\mathrm{Ba}-\mathrm{Ni}$ oxides shown by patterns $\mathrm{a}$ and $\mathrm{b}$ and patterns $\mathrm{d}$ and e in Figure 3. However, at $850-900{ }^{\circ} \mathrm{C}$ the reaction in the $0.1 \mathrm{KBNNO}$ slowed down, corresponding to the identical structures shown by patterns $\mathrm{b}$ and $\mathrm{c}$ in Figure 3. The same situation did not occur in the $0.2 \mathrm{KBNNO}$, where the rate of the reaction was still increasing, reflecting the on-going diffusion shown in patterns e and $\mathrm{f}$ in Figure 3.

It is expected that the increased temperature may cause extended potassium loss [2]. Table 2 illustrates the amount of further $\mathrm{K}$ loss for the $0.1 \mathrm{KBNNO}$ and $0.2 \mathrm{KBNNO}$ samples calcined at $850^{\circ} \mathrm{C}$ and $900{ }^{\circ} \mathrm{C}$ compared to those calcined at $800^{\circ} \mathrm{C}$. The $\mathrm{K}$ loss was calculated from the XRF results where the molecular percentage of each element was detected. The original results of the XRF characterisation are shown in Table A1 in the appendix. Both the $0.1 \mathrm{KBNNO}$ and the $0.2 \mathrm{KBNNO}$ calcined at $800^{\circ} \mathrm{C}$ had a secondary phase of Ba-Nb and Ba-Ni oxides (see Fig. 3), implying that some K-based compositions (oxides or hydroxide) were leftover in the structures. This caused further $\mathrm{K}$ losses when both compositions were calcined at $850{ }^{\circ} \mathrm{C}(2.0 \%$ and $1.8 \%$, respectively). The further $\mathrm{K}$ loss for the $0.1 \mathrm{KBNNO}$ slowed down when calcined at $900^{\circ} \mathrm{C}\left(0.5 \%\right.$ more compared to that at $\left.850^{\circ} \mathrm{C}\right)$, due to a relatively complete phase formation that occurred at $850^{\circ} \mathrm{C}$ (Fig. 3) and thus resulting in much less standalone K-based compositions remaining. The further $\mathrm{K}$ loss for the $0.2 \mathrm{KBNNO}$ also slowed down when calcined at $900^{\circ} \mathrm{C}$. However, there was still $1 \%$ more compared to that at $850^{\circ} \mathrm{C}$ which is twice the percentage for the $0.1 \mathrm{KBNNO}$. This may be because the diffusion of the $\mathrm{Ba}-\mathrm{Nb}$ and $\mathrm{Ba}-\mathrm{Ni}$ oxides was on-going at $850{ }^{\circ} \mathrm{C}$ (Fig. 3), leading to more left-over K-based compositions volatilized at $900{ }^{\circ} \mathrm{C}$ compared to the case of the $0.1 \mathrm{KNBNNO}$.

The XRD patterns of powders of the $5 \mathrm{KNBNNO}$ compositions calcined at $850^{\circ} \mathrm{C}$, in addition to those of the $0.02 \mathrm{KNBNNO}$ calcined at $650^{\circ} \mathrm{C}$ and $750^{\circ} \mathrm{C}$, are shown in Figure 4. All the calcined powders formed single orthorhombic perovskite phases with evidence of broadening of the $(022) /(200)$ peaks. The calcination of the $0.02 \mathrm{KNBNNO}$ at $650{ }^{\circ} \mathrm{C}$ led to the presence of the secondary phase i.e. Ba-Nb oxides, similar to the situation in the KBNNO compositions shown in Figure 3. The secondary phase disappeared when calcined at $750^{\circ} \mathrm{C}$, but the $(022) /(200)$ peak broadening was not as obvious as that calcined at $850^{\circ} \mathrm{C}$, indicating less asymmetry of the unit cells calcined at $750^{\circ} \mathrm{C}$. Despite the fact of further $\mathrm{K}$ loss at relatively high temperatures, an increased temperature may at the same time help to obtain a structure as close to the target as possible (i.e. with less secondary phase and higher 

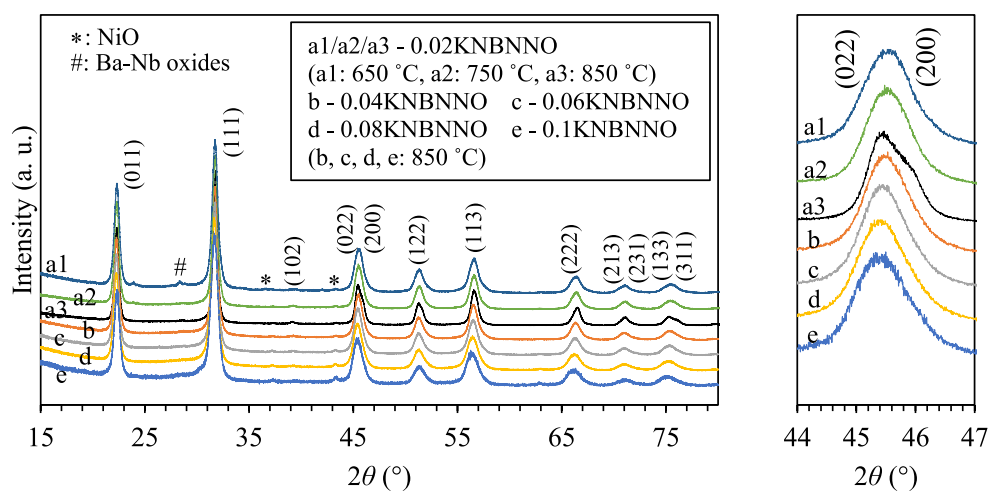

Fig. 4. XRD patterns of the powders of different KNBNNO compositions calcined at $850{ }^{\circ} \mathrm{C}$ and the $0.02 \mathrm{KNBNNO}$ calcined at $650^{\circ} \mathrm{C}$ and $750{ }^{\circ} \mathrm{C}$.
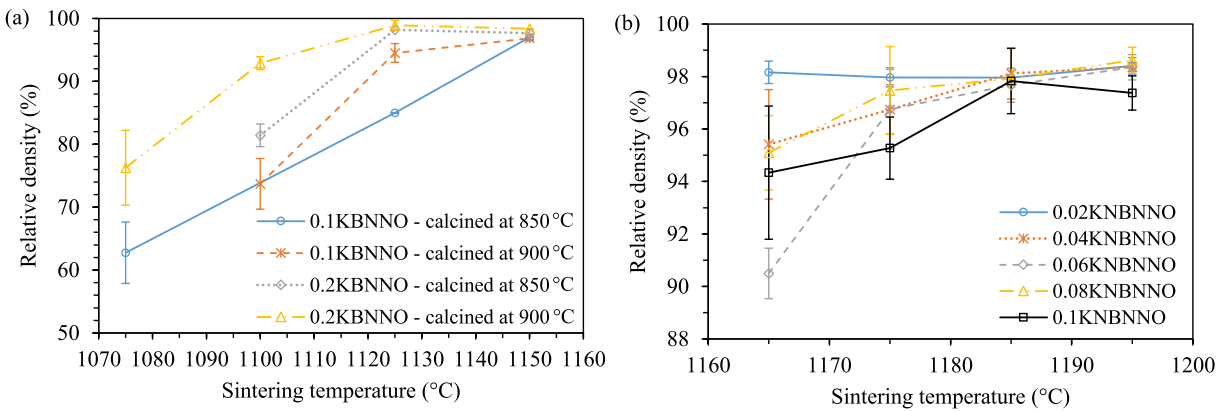

Fig. 5. Dependence of sintered density on sintering temperature for the (a) KBNNO and (b) KNBNNO ceramics with different compositions.

asymmetry of the unit cells). From this point of view, the KNBNNO compositions would benefit more than their KBNNO counterparts because of their negligible $\mathrm{K}$ loss at $>800{ }^{\circ} \mathrm{C}$. Taking into account the above-mentioned results together with some previous works $[1,10]$, the KNBNNO compositions were calcined at $850{ }^{\circ} \mathrm{C}$ in order to exclude any secondary phase. The increased concentration of BNNO dopant also increased the relative amount of the $\mathrm{NiO}$ phase left over, with evidence of more intensified corresponding peaks from $0.02 \mathrm{KNBNNO}$ to $0.1 \mathrm{KNBNNO}$, as shown in Figure 4. Although it is a minor secondary phase, the observable level of its existence in the relatively heavily doped compositions, such as $0.1 \mathrm{KNBNNO}$, could also be found in the $0.1 \mathrm{KBNNO}$ and $0.2 \mathrm{KBNNO}$ in which similar doping concentrations were applied. A potential reason for this is that the increased oxygen vacancies introduced with the increase of dopant BNNO caused larger degrees of distortion of the unit cells (i.e. oxygen octahedra), leading to reduced tolerance of $\mathrm{Ni}$ atoms in the structure.

Figure 5 shows the relative density of the ceramics sintered at different temperatures for different KBNNO and KNBNNO compositions. It is clear from Figure 5a that a higher calcination temperature of the powder was likely to result in a lower sintering temperature of the ceramics. For instance, the $850^{\circ} \mathrm{C}$ calcined $0.1 \mathrm{KBNNO}$ exhibited a much lower density than its $900^{\circ} \mathrm{C}$ calcined counterpart when both were sintered at $1125^{\circ} \mathrm{C}$. Similarly, the $900^{\circ} \mathrm{C}$ calcined $0.2 \mathrm{KBNNO}$ obtained a much larger density than the $850^{\circ} \mathrm{C}$ calcined when sintered at $1100^{\circ} \mathrm{C}$. With sufficiently high sintering temperatures, the influence of the calcination temperature diminished. 


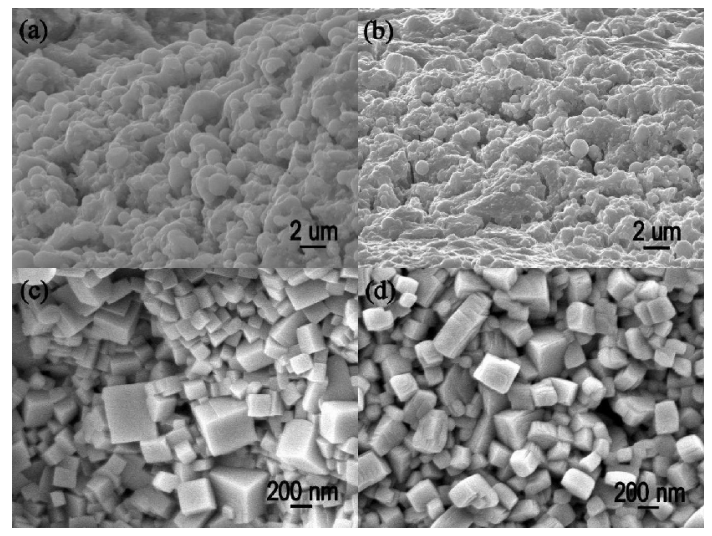

Fig. 6. SEM images of the fracture surfaces of (a) $0.1 \mathrm{KBNNO}$ calcined at $900^{\circ} \mathrm{C}$ and sintered at $1125^{\circ} \mathrm{C}$, (b) $0.2 \mathrm{KBNNO}$ calcined at $900^{\circ}$ and sintered at $1125^{\circ} \mathrm{C}$, (c) $0.02 \mathrm{KNBNNO}$ calcined at $850^{\circ} \mathrm{C}$ and sintered at $1165^{\circ} \mathrm{C}$, and (d) $0.04 \mathrm{KNBNNO}$ calcined at $850^{\circ} \mathrm{C}$ and sintered at $1175^{\circ} \mathrm{C}$.

The same densities were achieved for the $0.1 \mathrm{KBNNO}$ and $0.2 \mathrm{KBNNO}$ calcined at different temperatures when sintered at $1125-1150{ }^{\circ} \mathrm{C}$ and $1150{ }^{\circ} \mathrm{C}$, respectively (Fig. 5a). However, considering the aim of $\mathrm{K}$ loss suppression, a balance of the selections of calcination and sintering temperatures is needed. A lower temperature that is still enough to induce an effective chemical reaction and a relatively complete phase formation may be preferred. Meanwhile, the sintering temperature should also be kept as low as possible. As shown in Figure 5b, although well-sintered densities could be achieved with a range of sintering temperatures (e.g. $1165-1195^{\circ} \mathrm{C}$ for $0.02 \mathrm{KNBNNO}$ and $1175-1195{ }^{\circ} \mathrm{C}$ for $0.04 \mathrm{KNBNNO}, 0.06 \mathrm{KNBNNO}$ and $0.08 \mathrm{KNBNNO}$ ), higher sintering temperatures may lead to further $\mathrm{K}$ loss, thus causing deterioration of the functional properties [3]. Figure 6 shows the SEM images of some representative examples. The grain sizes of all of the four samples shown in the figure were similar $(200-500 \mathrm{~nm})$.

The XRD patterns of the well sintered ceramics of the KBNNO and KNBNNO are given in Figure 7. It has been shown in Figure 3 that, calcined at $800^{\circ} \mathrm{C}$, the $0.1 \mathrm{KBNNO}$ powder did not completely form into the dominant phase but left some minor amounts of Ba-Nb oxides. These subsequently formed the monolithic $\mathrm{Nb}_{2} \mathrm{O}_{5}$ secondary phase present in the sintered ceramic counterpart, as shown in Figure 7a. By contrast, the $0.1 \mathrm{KBNNO}$ achieved a complete formation of the perovskite phase when calcined at $850^{\circ} \mathrm{C}$ and above (Fig. 3). Such a single phase structure without excessive $\mathrm{Nb}_{2} \mathrm{O}_{5}$ was maintained after sintering (Fig. 7a). Revealed in Figure 3, despite the existence of some excessive $\mathrm{Nb}_{2} \mathrm{O}_{5}$, the $0.2 \mathrm{KBNNO}$ powder had a purer phase when calcined at $900^{\circ} \mathrm{C}$, i.e. the removal of Ba-Nb oxides phases, compared to that calcined at $850{ }^{\circ} \mathrm{C}$. However, the incomplete phase formation at $850^{\circ} \mathrm{C}$ was compensated during the sintering, as shown in Figure 7a, where the same patterns were obtained for the $0.2 \mathrm{KBNNO}$ ceramics with calcination temperatures of $850{ }^{\circ} \mathrm{C}$ and $900^{\circ} \mathrm{C}$. These phenomena indicated by Figure 7 reflect the above discussions concerning the determination of the calcination and sintering temperatures. A relatively low calcination temperature suppressed $\mathrm{K}$ loss, but was less helpful for a complete phase formation. A relatively high calcination temperature stimulated the phase formation, but increased the potassium loss. Consequently, a moderate calcination temperature which ensures an expected phase formation in the combination of calcination and sintering and suppresses $\mathrm{K}$ loss to some extent should be chosen for a successful synthesis of the target composition. The KNBNNO 

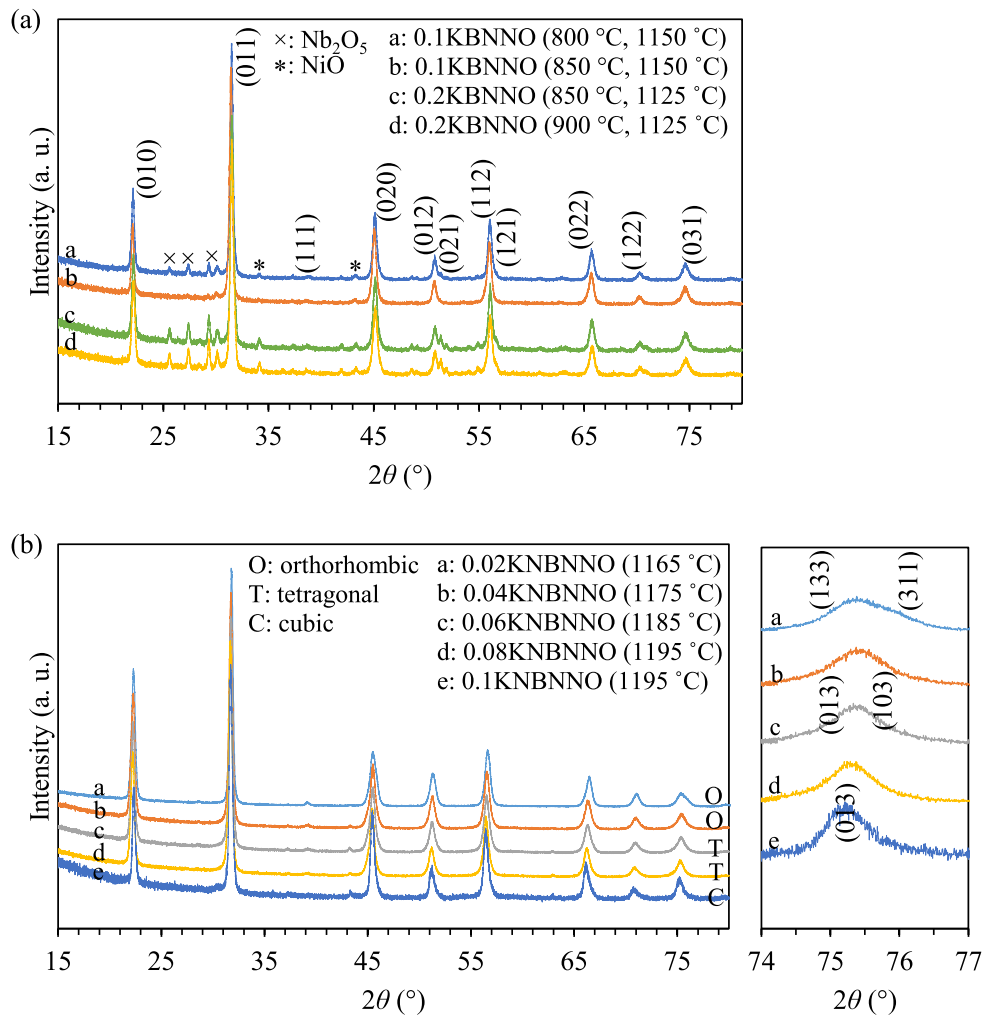

Fig. 7. XRD patterns of the well-sintered ceramics for different (a) KBNNO and (b) KNBNNO compositions. The temperatures labelled in (a) are the calcination and sintering temperatures of the corresponding powders. The temperatures labelled in (b) are corresponding sintering temperatures. The calcination temperature of all KNBNNO compositions in (b) is the same $\left(850^{\circ} \mathrm{C}\right)$.

compositions experienced orthorhombic-tetragonal and tetragonal-cubic phase transitions between $y=0.04-0.06$ and $y=0.08-0.1$, respectively, as shown in Figure 7b. All compositions formed single perovskite phases, implying a correct determination of the calcination and sintering temperatures.

\subsection{Hygroscopicity and dielectric properties}

It is well known that pure $\mathrm{KN}$ and $\mathrm{KNN}$ are strongly hygroscopic due to the presence of alkaline elements in the structures [29,30]. This means if stored in air atmosphere with relatively high humidity, the sintered KN and KNN ceramics will adsorb water over time. The adsorbed water easily reacts with the alkaline elements, leading to destruction of KN and KNN unit cells thus changed dielectric properties. This change may mean considerably increased the dielectric loss, which should be avoided in practice. In order to investigate the hygroscopicity of the KBNNO and KNBNNO, the sintered and un-poled ceramics were successively treated in:

- a $60 \%$ humidity air atmosphere;

- a dessicator filled with dried silica gel; and

- an oven at an elevated temperature $\left(120^{\circ} \mathrm{C}\right)$. 

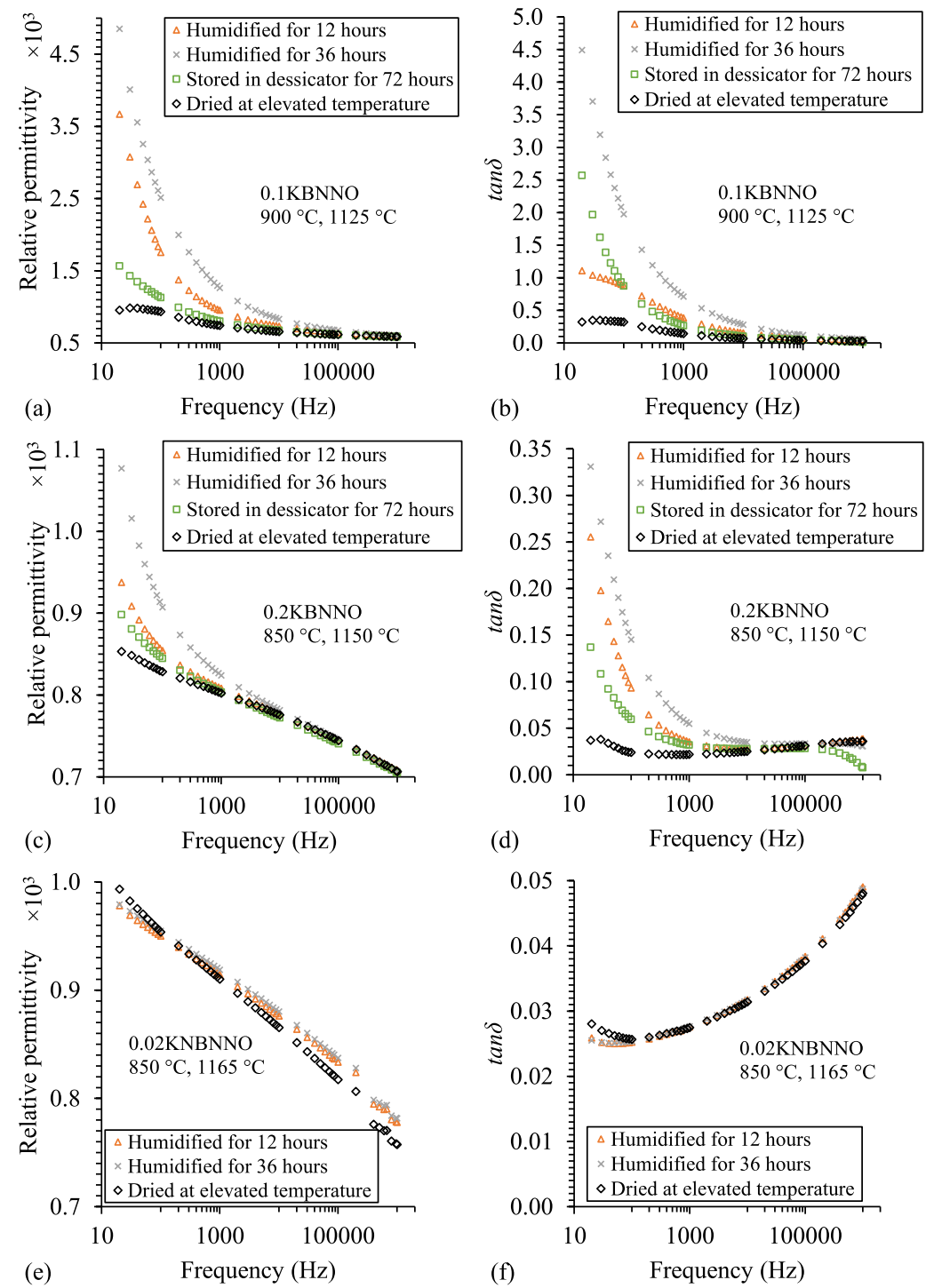

Fig. 8. Dependence of relative permittivity and dielectric loss (tan $\delta$ ) as a function of frequency for (a), (b) $0.1 \mathrm{KBNNO}$ calcined at $900^{\circ} \mathrm{C}$ and sintered at $1125^{\circ} \mathrm{C}$, (c), (d) $0.2 \mathrm{KBNNO}$ calcined at $850^{\circ} \mathrm{C}$ and sintered at $1150^{\circ} \mathrm{C}$ and (e), (f) $0.02 \mathrm{KNBNNO}$ calcined at $850^{\circ} \mathrm{C}$ and sintered at $1165^{\circ} \mathrm{C}$ after being aged with different humidity.

After each process, the dielectric properties were measured. Figure 8 shows the results for the $0.1 \mathrm{KBNNO}$ calcined at $900^{\circ} \mathrm{C}$ and sintered at $1125^{\circ} \mathrm{C}$, the $0.2 \mathrm{KBNNO}$ calcined at $850^{\circ} \mathrm{C}$ and sintered at $1150^{\circ} \mathrm{C}$, and the $0.02 \mathrm{KNBNNO}$ calcined at $850^{\circ} \mathrm{C}$ and sintered at $1165^{\circ} \mathrm{C}$, as labelled in the figure. The changes in the properties of the $0.1 \mathrm{KBNNO}$ and $0.2 \mathrm{KBNNO}$ are very clear (Figs. 8a-8d). For both compositions, compared to the dry status (dried at elevated temperature), the relative permittivity and dielectric loss $(\tan \delta)$ increased sharply with the duration of storage in the humidified atmosphere. After being stored in the dry atmosphere (dessicator), these dielectric properties reverted to those of the dry status, although not completely. The property changes showed large gaps at relatively low frequencies, 
Table 3. Summary of changes of the relative permittivity and dielectric loss after being humidified for $36 \mathrm{~h}$ in respect to the values of dry status and measured at $1 \mathrm{kHz}$ for the $0.1 \mathrm{KBNNO}, 0.2 \mathrm{KBNNO}$ and $0.02 \mathrm{KNBNNO}$ ceramics.

\begin{tabular}{lllll}
\hline Composition & $\begin{array}{l}\text { Calcination } \\
\text { temperature }\left({ }^{\circ} \mathrm{C}\right)\end{array}$ & $\begin{array}{l}\text { Sintering } \\
\text { temperature }\left({ }^{\circ} \mathrm{C}\right)\end{array}$ & $\begin{array}{l}\text { Change of relative } \\
\text { permittivity }(\%)\end{array}$ & $\begin{array}{l}\text { Change of } \\
\text { dielectric loss }(\%)\end{array}$ \\
\hline 0.1 KBNNO & 850 & 1125 & $216^{a}$ & 218 \\
& 850 & 1150 & 5 & 187 \\
& 900 & 1125 & 70 & 390 \\
& 900 & 1150 & 1 & 67 \\
$0.2 \mathrm{KBNNO}$ & 850 & 1125 & 3 & 167 \\
& 850 & 1150 & 3 & 150 \\
& 900 & 1125 & $<1$ & 78 \\
$0.02 \mathrm{KNBNNO}$ & 850 & 1150 & $<1$ & $<1$ \\
\hline
\end{tabular}

${ }^{a}$ All numbers are positive i.e. the value is increasing.

i.e. $<1 \mathrm{kHz}$, and then became smaller with the increase of frequency. In comparison, the changes in the properties of the $0.02 \mathrm{KNBNNO}$ were negligible (Figs. 8e and 8f). The changes of the relative permittivity and dielectric loss (after being humidified for $36 \mathrm{~h}$ ) in respect to the values (measured at $1 \mathrm{kHz}$ ) of the dry status for the $0.1 \mathrm{KBNNO}, 0.2 \mathrm{KBNNO}$ and $0.02 \mathrm{KNBNNO}$ ceramics are summarised in Table 3. There was a significant deviance in the changes of relative permittivity between different compositions and calcination and sintering temperatures. The density of the ceramics is not considered to be the main reason for this because all the ceramics listed in Table 3 achieved similar and relatively high levels of densification compared to their corresponding theoretical densities (see Fig. 5a). The only exception was the $0.1 \mathrm{KBNNO}$ calcined at $850^{\circ} \mathrm{C}$ and sintered at $1125^{\circ} \mathrm{C}$, which had a lower level of densification compared to other counterparts (see Fig. 5a). For this sample, the change was considerably larger $(>200 \%)$, partially due to water absorption by the pores existing in the microstructure of the ceramics. On the other hand, those pores may also have made the sample to be much more lossy than the other samples (see Figs. 5b, 5d and 5e). In a general comparison, the $0.2 \mathrm{KBNNO}$ showed a better stability in terms of the changes of both relative permittivity and dielectric loss than the $0.1 \mathrm{KBNNO}$. It might be possible that a potassium deficit in the microstructure could make the ceramics less hygroscopic. However, 0.1 KBNNO and 0.2 KBNNO are commonly very hygroscopic, especially leading to a varying dielectric loss when stored and used in a humid environment. The $0.02 \mathrm{KNBNNO}$ appeared to have a better stability than the $0.1 \mathrm{KBNNO}$ and $0.2 \mathrm{KBNNO}$ in a humid environment.

The absolute values of the relative permittivity (measured at $1 \mathrm{kHz}$ with dry condition) of KBNNO and KNBNNO ranged from 700 to 1000 (Fig. 8), much smaller than those of widely used ferroelectric materials (e.g. PZT and $\mathrm{BaTiO}_{3}$ with relative permittivity of $1500-5000[11,12])$ for energy harvesters. It is known that smaller permittivity helps to increase figures of merit of piezoelectric and pyroelectric energy harvesters $[11,12]$. For instance, because of the relatively small permittivity, the optimum KNBNNO composition, i.e. 0.02 KNBNNO, obtained comparable piezoelectric figure of merit $\left(1.2 \times 10^{-12} \mathrm{~m}^{2} / \mathrm{N}\right)$ [27] to that of $\mathrm{BaTiO}_{3}\left(2.1 \times 10^{-12} \mathrm{~m}^{2} / \mathrm{N}\right)[11]$. Here, the figure of merit is defined as $\mathrm{d}_{33} / \varepsilon_{r} \varepsilon_{0}$, where $\mathrm{d}_{33}$ is piezoelectric charge coefficient and $\varepsilon_{r}$ and $\varepsilon_{0}$ are relative and vacuum permittivity, respectively. A larger figure of merit tends to induce a better kinetic energy harvesting output, assuming other factors like input energy, device configuration, etc. are kept the same [11]. However, like most of lead-free ferroelectric counterparts, it is admitted that the 

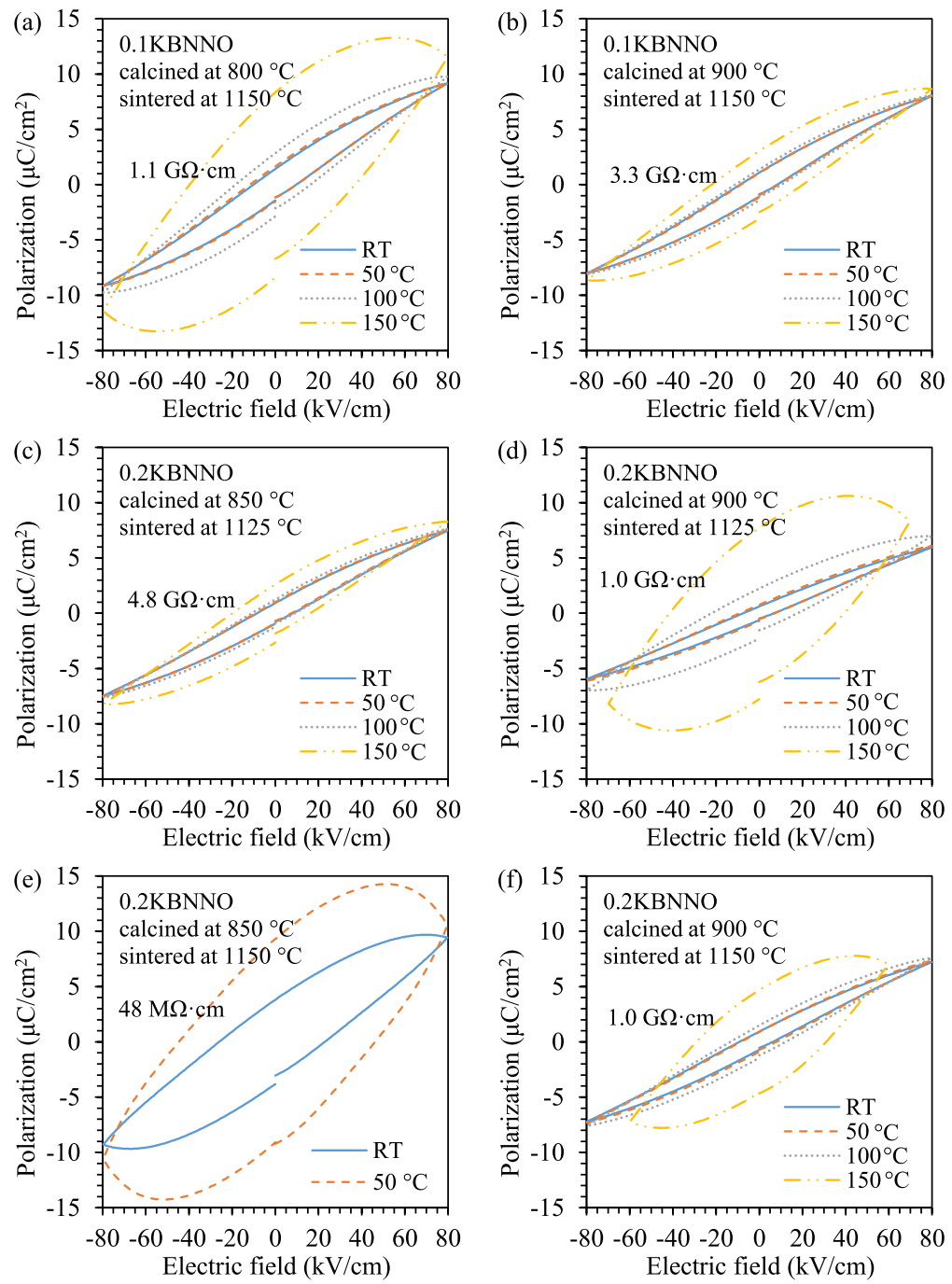

Fig. 9. Dependence of polarization on electric field measured with $1 \mathrm{~Hz}$ and at different temperatures for the $0.1 \mathrm{KBNNO}$ and $0.2 \mathrm{KBNNO}$ ceramics. The electric resistivity marked in each figure is obtained at the highest temperature, i.e. at $50^{\circ} \mathrm{C}$ in (e) and $150{ }^{\circ} \mathrm{C}$ in (a)-(d) and (f). RT refers to room temperature.

energy harvesting capability of KBNNO and KNBNNO are still uncompetitive to that of lead-containing soft PZT (e.g. PZT-5H with figure of merit of $11.6 \times 10^{-12} \mathrm{~m}^{2} / \mathrm{N}$ [11]). Further investigation focusing on improving $\mathrm{d}_{33}$ or decreasing $\varepsilon_{r}$ will help to enhance the competitiveness of KBNNO and KNBNNO compared to PZT. Potential approaches may include structural texturing [37], introduction of porosity [38] and creation of composite containing KNBNNO and ferroelectric polymers (e.g. PVDF (Polyvinylidene fluoride)) [39].

\subsection{Ferroelectric properties}

Figure 9 shows the ferroelectric hysteresis loops (P-E loops) of the $0.1 \mathrm{KBNNO}$ and $0.2 \mathrm{KBNNO}$ ceramics measured with $1 \mathrm{~Hz}$ and at different temperatures. Although 
the ferroelectric properties of these two compositions have been discussed in detail in $[1,2]$, Figure 9 further implies that the KBNNO compositions may be very sensitive to calcination and sintering temperatures in relation to their electric conductivities and ferroelectric properties. In Figure 9a, for the P-E loop measured at $150{ }^{\circ} \mathrm{C}$, the polarization at the maximum electric field is smaller than the maximum polarization of the loop. This is a typical lossy P-E loop caused by increased conductivity (decreased resistivity) of the sample [18]. By contrast, in Figure 9b the counterpart is a normal (though unsaturated) loop, with the resistivity of the sample being 3 times that in Figure 9a. The only difference between the samples is that the $0.1 \mathrm{KBNNO}$ was calcined at $800^{\circ} \mathrm{C}$ for Figure $9 \mathrm{a}$ but at $900^{\circ} \mathrm{C}$ for Figure $9 \mathrm{~b}$. They were both sintered at $1150^{\circ} \mathrm{C}$. It has been discussed with Figure 3 that the phase formation of the $0.1 \mathrm{KBNNO}$ calcined at $800^{\circ} \mathrm{C}$ was not as complete as that calcined at $900^{\circ} \mathrm{C}$. This subsequently resulted in excessive $\mathrm{Nb}_{2} \mathrm{O}_{5}$ left in the structure (Fig. 7a), implying that a corresponding amount of potassium which was meant to bind with niobium in the dominant phase may be lost. Consequently, vacancies may be created, leading to decreased resistivity.

The above discussion can be further supported by Figures 9c-9f with the $0.2 \mathrm{KBNNO}$. In Figure 9c, the sample was calcined and sintered at moderate temperatures $\left(850^{\circ} \mathrm{C}\right.$ and $1125^{\circ} \mathrm{C}$, respectively) with minimised $\mathrm{K}$ loss and the most complete phase formation possible resulting in normal P-E loops being induced. In Figure 9d, the samples was also sintered at $1125^{\circ} \mathrm{C}$, but was calcined at $900^{\circ} \mathrm{C}$. Although the $0.2 \mathrm{KBNNO}$ calcined at $900^{\circ} \mathrm{C}$ showed a more complete phase formation than that calcined at $850^{\circ} \mathrm{C}$ (according to Fig. 3 and relevant discussions above), because the $0.2 \mathrm{KBNNO}$ was initially designed to have a potassium deficit, even a complete phase formation had excessive $\mathrm{Nb}_{2} \mathrm{O}_{5}$ left over. Meanwhile, the increased calcination temperature of $900{ }^{\circ} \mathrm{C}$ may have lead to further $\mathrm{K}$ loss compared to $850{ }^{\circ} \mathrm{C}$ (see Tab. 2), whilst creating more vacancies in the unit cells. As a result, the resistivity measured at $150^{\circ} \mathrm{C}$ shown in Figure $9 \mathrm{~d}$ is only about $20 \%$ of that shown in Figure 9c. The resistivity in Figure 9d is about the same value of that in Figure 9a. This leads to similarly shaped lossy P-E loops in these figures. The potassium loss could have become worse if the sintering temperature had been increased. Comparing Figures 9c and $9 \mathrm{e}$, both the samples were calcined at $850^{\circ} \mathrm{C}$ but sintered at $1125^{\circ} \mathrm{C}$ and $1150^{\circ} \mathrm{C}$, respectively. The sample in Figure $9 \mathrm{e}$ exhibited only $1 \%$ of the resistivity of that in Figure 9c. Therefore, the abnormal, lossy P-E loop in Figure 9e appeared earlier (at $50^{\circ} \mathrm{C}$ rather than $150{ }^{\circ} \mathrm{C}$ ) and was more exaggerated (closer to a semi-roundish shaped loop). The acceleration of the potassium volatilization rate at higher sintering temperatures is very clear at this point. Comparing Figures $9 \mathrm{~d}$ and $9 \mathrm{f}$ where the samples were calcined at $900^{\circ} \mathrm{C}$ and sintered at $1125^{\circ} \mathrm{C}$ and $1150^{\circ}$, respectively, the difference in the resistivity is not found. This indicates that a complete phase formation at $900^{\circ} \mathrm{C}$ may help to hold the potassium in the unit cells more firmly, thus reducing further $\mathrm{K}$ loss at higher temperatures during sintering. The lossy P-E loop in Figure $9 \mathrm{f}$ is only due to the $\mathrm{K}$ loss and resistivity reduction in the calcination. In summary, Figure 9 implies that the calcination and sintering windows in terms of temperatures are very narrow for the $0.1 \mathrm{KBNNO}$ and $0.2 \mathrm{KBNNO}$ compositions. In order to maintain normally shaped P-E loops and thus to investigate their true ferroelectric properties, a minimum resistivity of approximately $3 \mathrm{G} \Omega \mathrm{cm}$ is required.

The issue of potassium loss of the KNBNNO compositions has been briefly discussed in [3] with the ferroelectric data obtained at room temperatures. As with the hygroscopic issue, the phenomenon of potassium loss causing dramatically reduced resistivity and lossy P-E loops for the KNBNNO samples was observed only rarely compared to the case of the KBNNO samples. Only the $0.02 \mathrm{KNBNNO}$ and $0.04 \mathrm{KNBNNO}$ ceramics sintered at $1195^{\circ} \mathrm{C}$ showed semi-roundish shaped P-E loops and relatively low resistivity [3]. This may be due to the appropriate choice of the calcination temperature $\left(850^{\circ} \mathrm{C}\right)$ which induced complete single phase formation to 

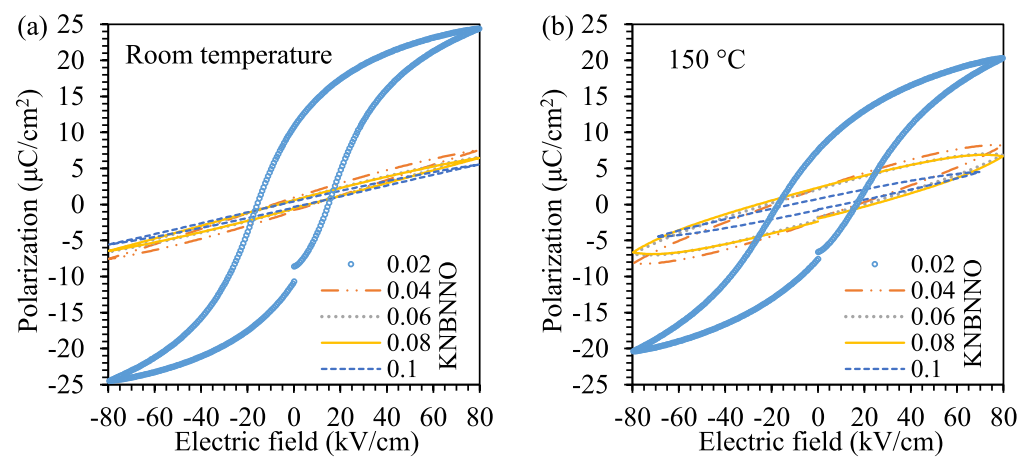

Fig. 10. Dependence of polarization on electric field measured with $1 \mathrm{~Hz}$ and at (a) room temperature and (b) $150^{\circ} \mathrm{C}$ for different KNBNNO ceramics calcined at $850^{\circ} \mathrm{C}$ and sintered at the best sintering temperatures.

the greatest extent (see Figs. 4 and 5b). Meanwhile, it seems that a minimum resistivity of about $3.5-4 \mathrm{G} \Omega \mathrm{cm}$ is required in order to obtain normally shaped P-E loops [3]. Figure 10 shows the P-E loops of the KNBNNO ceramics measured with $1 \mathrm{~Hz}$ and at different temperatures. The samples were selected based on the criteria of:

- the P-E loops not being lossy at any of the measuring temperatures (or at least at room temperature);

- the sintering temperature being as low as possible (less potential potassium loss);

- the sintered density being as high as possible; and

- the remanent polarization being as large as possible.

As a result, the sintering temperatures of the samples shown in Figure 10 were $1165^{\circ} \mathrm{C}(0.02 \mathrm{KNBNNO}), 1175^{\circ} \mathrm{C}(0.04 \mathrm{KNBNNO}), 1185^{\circ} \mathrm{C}(0.06 \mathrm{KNBNNO})$ and $1195^{\circ} \mathrm{C}(0.08 \mathrm{KNBNNO}$ and $0.1 \mathrm{KNBNNO})$. These temperatures represent the best sintering temperatures of the corresponding compositions. The $0.02 \mathrm{KNBNNO}$ has been specifically reported and discussed in [3]. Its giant ferroelectric properties (Fig. 10a) together with its narrow bandgap make this particular composition significantly advantageous not only over all the other KBNNO and KNBNNO compositions but also over other conventional ferroelectric ceramics [3]. Even when measured at an elevated temperature $-150^{\circ} \mathrm{C}$ at which most KBNNO and KNBNNO compositions failed to withstand a relatively large resistivity, thus unable to maintain a standard P-E loop (see Figs. 9 and 10b) - the 0.02 KNBNNO could still exhibit a saturated, typical P-E loop with substantial remanent polarization. In comparison, as mentioned above, the $0.04 \mathrm{KNBNNO}, 0.06 \mathrm{KNBNNO}$ and $0.08 \mathrm{KNBNNO}$ showed slim, unsaturated P-E loops, despite the fact that at $150{ }^{\circ} \mathrm{C}$ their remanent polarizations were increased to a recognisable extent compared to those at room temperature.

Finally, in terms of potential scaling-up or mass production of KBNNO and KNBNNO, as discussed above a temperature controlling accuracy of $10^{\circ} \mathrm{C}$ will be necessary during calcination and sintering in order to ensure the achievement of ideal properties. Although the sintering temperatures of KN- or KNN-based compositions are close to corresponding melting points, prospective scalability and mass production will not be hindered by such an issue. This is because even if the $10^{\circ} \mathrm{C}$ accuracy would not be guaranteed, other approaches can be implemented to reduce the sintering temperature thus pulling it away from the melting point. Potential approaches include reducing particle size and/or adopting LTCC (low temperature co-fired ceramics) techniques [40-42]. 


\section{Conclusions}

Two compositions of the KBNNO and five compositions of the KNBNNO have been fabricated and characterised. Different calcination and sintering temperatures of the powders and ceramics have, by affecting the rate of potassium loss, resulted in different microstructures of the compositions. These different microstructures have determined the varying hygroscopicity of the ceramics as well as their different dielectric and ferroelectric properties. In these photo-ferroelectric multi-functional perovskites, the remanent polarization at the operating temperature should be as large as possible. This can benefit not only the potentially strong piezoelectric and pyroelectric response but also boost the photovoltaic effect $[14,15]$. However, the large remanent polarization and narrow band gap can only be simultaneously achieved in a very narrow window of the composition and processing temperature when the formation of the major phase (orthorhombic) and the minimization of oxygen vacancies are properly balanced.

Open access funding provided by the University of Oulu, Finland. This work has received funding from the European Union's Horizon 2020 research and innovation program under the Marie Sklodowska-Curie grant agreement number 705437. Author J.J. acknowledges the funding of the Academy of Finland (project numbers 267573, 273663 and 298409). The authors acknowledge the Centre of Microscopy and Nanotechnology of University of Oulu for the use of their facilities and for the fabrication of ITO electrodes. Author H. Xiang appreciates the financial support from the Natural Science Foundation of China (Nos. 51502047, 21561008, and 21761008), the Natural Science Foundation of Guangxi Zhuang Autonomous Region (Nos. 2015GXNSFFA139003, 2016GXNSFBA380134, and 2016GXNSFAA380018), Project of Scientific Research and Technical Exploitation Program of Guilin (Nos. 2016010702-2 and 20170225).

\section{Author contribution statement}

Y.B. fabricated the samples, carried out the characterizations, analysed the data and drafted the manuscript. H.X. assisted the sample fabrication and processing. Y.B., H.J. and J.J. co-wrote the paper.

Open Access This is an open access article distributed under the terms of the Creative Commons Attribution License (http://creativecommons.org/licenses/by/4.0), which permits unrestricted use, distribution, and reproduction in any medium, provided the original work is properly cited.

\section{References}

1. V.M. Fridkin, Photoferroelectrics (Springer, Berlin, 1979)

2. B.I. Sturman, V.M. Fridkin, The photovoltaic and photorefractive effects in noncentrosymmetric materials (Bordon and Breach, Amsterdam, 1992)

3. V.M. Fridkin, IEEE Trans. Ultrason. Ferroelectr. Freq. Control 60, 1551 (2013)

4. J.E. Spanier, V.M. Fridkin, A.M. Rappe, A.R. Akbashev, A. Polemi, Y. Qi, Z. Gu, S.M. Young, C.J. Hawley, D. Imbrenda, G. Xiao, A.L. Bennett-Jackson, C.L. Johnson, Nat. Photonics 10, 688 (2016)

5. C. Paillard, X. Bai, I.C. Infante, M. Guennou, G. Geneste, M. Alexe, J. Kreisel, B. Dkhil, Adv Mater. 28, 5153 (2016)

6. I. Grinberg, D.V. West, M. Torres, G. Gou, D.M. Stein, L. Wu, G. Chen, E.M. Gallo, A.R. Akbashev, P.K. Davies, J.E. Spanier, A.M. Rappe, Nature 503, 509 (2013) 
7. A. Polman, M. Knight, E.C. Garnett, B. Ehrler, W.C. Sinke, Science 352, aad4424 (2016)

8. G.K. Singh, Energy 53, 1 (2013)

9. D. Damjanovic, Rep. Prog. Phys. 61, 1267 (1998)

10. J. Roedel, W. Jo, K.T.P. Seifert, E. Anton, T. Granzow, D. Damjanovic, J. Am. Ceram. Soc. 92, 1153 (2009)

11. C.R. Bowen, H.A. Kim, P.M. Weaver, S. Dunn, Energy Environ. Sci. 7, 25 (2014)

12. C.R. Bowen, J. Taylor, E. LeBoulbar, D. Zabek, A. Chauhan, R. Vaish, Energy Environ. Sci. 7, 3836 (2014)

13. Y. Bai, H. Jantunen, J. Juuti, Adv. Mater. 2018, 1707271 (2018)

14. G. Vats, Y. Bai, D. Zhang, J. Juuti, J. Seidel, Adv. Optic. Mater. 2019, 1800858 (2019)

15. Y. Bai, G. Vats, J. Seidel, H. Jantunen, J. Juuti, Adv. Mater. 2018, 1803821 (2018)

16. R. Nechache, C. Harnagea, S. Li, L. Cardenas, W. Huang, J. Chakrabartty, F. Rosei, Nat. Photonics 9, 61 (2015)

17. J. Chakrabartty, C. Harnagea, M. Celikin, F. Rosei, R. Nechache, Nat. Photonics 12, $271(2018)$

18. N. Faraji, R. Adelung, Y.K. Mishra, J. Seidel, Nanotechnology 28, 405701 (2017)

19. N. Faraji, C. Ulrich, N. Wolff, L. Kienle, R. Adelung, Y.K. Mishra, J. Seidel, Adv. Electron. Mater. 2, 1600138 (2016)

20. S.Y. Yang, J. Seidel, S.J. Byrnes, P. Shafer, C. Yang, M.D. Rossell, P. Yu, Y.-H. Chu, J.F. Scott, J.W. Ager III, L.W. Martin, R. Ramesh, Nat. Nanotechnol. 5, 143 (2010)

21. J.Y. Wang, G. Liu, D. Sando, V. Nagarajan, J. Seidel, Appl. Phys. Lett. 111, 092902 (2017)

22. J. Seidel, L.M. Eng, Curr. Appl. Phys. 14, 1083 (2014)

23. T. Choi, S. Lee, Y.J. Choi, V. Kiryukhin, S. Cheong, Science 324, 63 (2009)

24. P.S. Brody, Ferroelectric photovoltaic method and apparatus for transferring information, US Patent US4103341A, 1974

25. S. Thakoor, A.P. Thakoor, Thin film ferroelectric electro-optic memory, US Patent US5206829A, 1990

26. Y. Bai, T. Siponkoski, J. Perantie, H. Jantunen, J. Juuti, Appl. Phys. Lett. 110, 063903 (2017)

27. Y. Bai, P. Tofel, J. Palosaari, H. Jantunen, J. Juuti, Adv. Mater. 29, 1700767 (2017)

28. Y. Bai, Energy harvesters capable of simultaneously converting visible light, heat and kinetic energy into electricity based on only one energy conversion material and its fabrication method, Patent application

29. H. Birol, D. Damjanovic, N. Setter, J. Am. Ceram. Soc. 88, 1754 (2005)

30. H. Birol, D. Damjanovic, N. Setter, J. Eur. Ceram. Soc. 26, 861 (2006)

31. Q. Ma, B. Wan, L. Cheng, S. Liu, F. Liu, J. Electroceram. 36, 30 (2016)

32. M. Matsubara, T. Yamaguchi, W. Sakamoto, K. Kikuta, T. Yogo, S. Hirano, J. Am. Ceram. Soc. 88, 1190 (2005)

33. H. Ogawa, D. Iida, S. Takahashi, T. Moriyama, A. Kan, Ferroelectrics 497, 52 (2016)

34. S. Zhang, R. Xia, T.R. Shrout, G. Zang, J. Wang, J. Appl. Phys. 100, 104108 (2006)

35. W. Zhou, H. Deng, P. Yang, J. Chu, Appl. Phys. Lett. 105, 111904 (2014)

36. E. Irle, R. Blachnik, B. Gather, Thermochim. Acta 179, 157 (1991)

37. A.B. Haugen, G.H. Olsen, F. Madaro, M.I. Morozov, G. Tutuncu, J.L. Jones, T. Grande, M. Einarsrud, J. Am. Ceram. Soc. 97, 3818 (2014)

38. Y. Zhang, M. Xie, J. Roscow, Y. Bao, K. Zhou, D. Zhang, C.R. Bowen, J. Mater. Chem. A 5, 6569 (2017)

39. V. Vivekananthan, N.R. Alluri, Y. Purusothaman, A. Chandrasekhar, S. Kim, Nanoscale 9, 15122 (2017)

40. M.T. Sebastian, H. Jantunen, Int. Mater. Rev. 53, 57 (2008)

41. M.T. Sebastian, R. Ubic, H. Jantunen, Int. Mater. Rev. 60, 392 (2015)

42. M.T. Sebastian, H. Wang, H. Jantunen, Curr. Opin. Solid State Mater. Sci. 20, 151 (2016) 


\section{Appendix}
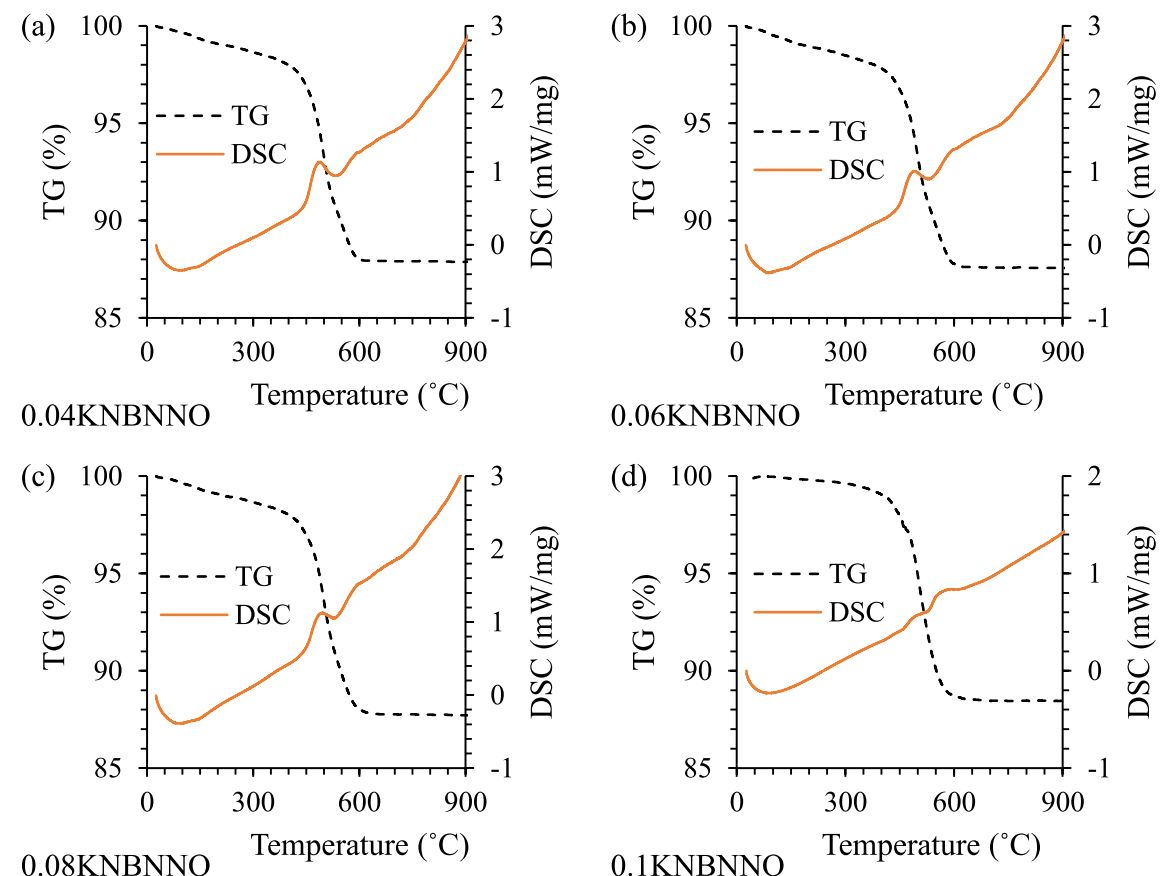

Fig. A1. DSC and TG data as a function of temperature for the mixtures of reactants of (a) $0.04 \mathrm{KNBNNO}$, (b) $0.06 \mathrm{KNBNNO}$, (c) $0.08 \mathrm{KNBNNO}$ and (d) $0.1 \mathrm{KNBNNO}$.

Table A1. Elemental molecular percentage of the $0.1 \mathrm{KBNNO}$ and $0.2 \mathrm{KBNNO}$ powders calcined at different temperatures.

\begin{tabular}{|c|c|c|c|c|c|c|}
\hline Elemental $\mathrm{n}$ & olecular percentage & \multirow{2}{*}{$\begin{array}{l}\mathrm{K} \\
(\mathrm{mol} . \%)\end{array}$} & \multirow{2}{*}{$\begin{array}{l}\mathrm{Ba} \\
(\mathrm{mol} . \%)\end{array}$} & \multirow{2}{*}{$\begin{array}{l}\mathrm{Nb} \\
(\mathrm{mol} . \%) \\
19.1\end{array}$} & \multirow{2}{*}{$\begin{array}{l}\mathrm{Ni} \\
(\mathrm{mol} . \%) \\
0.8\end{array}$} & \multirow{2}{*}{$\begin{array}{l}\text { O } \\
(\mathrm{mol} . \%)\end{array}$} \\
\hline \multirow{3}{*}{$0.1 \mathrm{KBNNO}$} & $\begin{array}{l}\text { Calcined at } \\
800^{\circ} \mathrm{C}\end{array}$ & & & & & \\
\hline & $\begin{array}{l}\text { Calcined at } \\
850^{\circ} \mathrm{C}\end{array}$ & 18.2 & 2.0 & 19.1 & 0.8 & 59.9 \\
\hline & $\begin{array}{l}\text { Calcined at } \\
900{ }^{\circ} \mathrm{C}\end{array}$ & 18.1 & 2.0 & 19.1 & 0.8 & 60.0 \\
\hline \multirow{3}{*}{$0.2 \mathrm{KBNNO}$} & $\begin{array}{l}\text { Calcined at } \\
800{ }^{\circ} \mathrm{C}\end{array}$ & 17.0 & 2.1 & 19.5 & 1.0 & 60.4 \\
\hline & $\begin{array}{l}\text { Calcined at } \\
850^{\circ} \mathrm{C}\end{array}$ & 16.8 & 2.1 & 19.6 & 1.0 & 60.6 \\
\hline & $\begin{array}{l}\text { Calcined at } \\
900{ }^{\circ} \mathrm{C}\end{array}$ & 16.6 & 2.1 & 19.6 & 1.0 & 60.7 \\
\hline
\end{tabular}

